\title{
EFFICACY OF TRACER 240 SC AND STEWARD 150 SC AGAINST FIRST AND SECOND INSTAR LARVAE OF HELICOVERPA ARMIGERA BY USING THE LEAF DIP METHOD
}

\author{
Rashad Rasool Khan*, Khuram Zia, Waqar Salman, Bakhtiar Salman
}

Department of Agriculture Entomology, University of Agriculture, Faisalabad, Pakistan

Received: April 21, 2010

Accepted: September 22, 2010

\begin{abstract}
Different concentrations of Steward 150 SC and Tracer 240 SC were tested under laboratory conditions against first and second instar larvae of Helicoverpa armigera. Results showed that these insecticides are very effective. The maximum mortality was observed by both insecticides and they can be used in the Integrated Plant Management (IPM) programme of any crop. For first instar, 300 ppm spinosad and 200 ppm indoxacarb can give complete mortality after 48 hours. For second instar larvae, 400 ppm spinosad can give maximum mortality (4.667), while 200 ppm of indoxacarb can give complete mortality after 48 hours.
\end{abstract}

Key words: Helicoverpa armigera, indoxacarb, spinosad, insecticidal mortality

\section{INTRODUCTION}

Helicoverpa armigera Hub. commonly known as American bollworm, is the major pest of many crops and considered as the most main pest of cotton, all over the world and also in Pakistan. It can cause a 15 percent decline in cotton crop yield (Regupathy et al. 1999). No plant seems to be strong enough to avoid attack of $H$. armigera (Thirasack 2001). Earlier reports showed that the Pyrethroids were the most potent against this pest and these insecticides reduced the population and damage of $H$. armigera effectively. But indiscriminate use of insecticides resulted in H. armigera becoming resistant to the insecticides. Now, it has also become difficult to control this pest because it has developed resistance against several conventional insecticides from the Organophosphate, Pyrethroid and Carbamate groups. Resistance has been reported from different parts of the world, especially from, New Zealand (Cameron et al. 1995), India (Ramasubramanian 2004), Australia (Gunning et al. 1992), Spain (Torres-Vila et al. 2002) and Pakistan (Ahmad et al. 1999).

Different control measures can be adopted to control this pest in which chemical control is the most important. Conventional insecticides are harmful to the beneficial insects and due to resistance in $H$. armigera it has become necessary to use such insecticides which are ecologically safe for natural enemies. Spinosad and indoxacarb belongs to a new chemical group of insecticides and are safe to the natural enemies of both predators (Nasreen et al. 2003) and parasitoids (Williams et al. 2003). These insecticides can be used in any Integrated Plant Management (IPM) program for the control of H. armigera because they are considered among the best insecticides to control the Lepidopteran pests (Ahmad et al. 2005).

In the present study, different concentrations of Indoxacarb 150 SC and Spinosad 240 SC were tested under laboratory conditions against first and second instar larvae of $H$. armigera. Comparisons were done to observe the optimum concentration of both insecticides.

\section{MATERIALS AND METHODS}

Insects

Full grown larvae of $H$. armigera were collected randomly from the field of chickpea during February 2005 and were reared at $27 \pm 2^{\circ} \mathrm{C}$, R.H. $60 \pm 5 \%$ and at a light darkness ratio of $14: 10$ hours, on chickpea based artificial diet. These larvae were reared to obtain the F1 generation, which was ultimately used in the experiment.

\section{Insecticides}

Commercial formulations of spinosad (Tracer 240 SC, Dow Agro Sciences) and indoxacarb (Steward 150 SC, DuPont) were obtained from their respective manufacturers and used in the present experiment. 100 ppm, 200 ppm, $300 \mathrm{ppm}$ and $400 \mathrm{ppm}$ concentrations were prepared by using distilled water. The first three concentrations were serial but the fourth serial concentration was skipped and the fifth was used as the fourth. This was done because if the serial concentrations did not show a significant effect then the fourth may be significant. 


\section{Bioassays}

Newly emerged first instar and newly moulted second instar larvae of F1 generation of $H$. armigera were exposed to the test insecticides at four different concentrations. The leaf dip method was used as recommended by the Insecticide Resistance Action Committee of GIFAP (Anonymous 1990). Unsprayed cotton leaves were taken, and washed. Five centimeter leaf discs were cut. These were dipped in test solutions for ten seconds with gentle agitation and were placed on filter paper for drying. The leaf discs were placed in a five centimeter glass petri dish with a thin layer of agar underneath to avoid desiccation in three replicates. On each leaf disc seven larvae were placed with a fine camel hair brush and petri dishes were covered with lids in order to keep everything under controlled environmental conditions. The same number of leaf discs per treatment were dipped into distilled water to serve as the control. Mortality at different concentration levels of both insecticides was recorded after 24 and 48 hours of the exposure to the insecticides.

\section{Data analysis}

Data was analyzed using computer based software M-STATC.

\section{RESULTS}

\section{First Instar}

The mortality of newly emerged first instar larvae of H. armigera was noted after 24 and 48 hours of treatment with four different concentrations (100 ppm, 200 ppm, $300 \mathrm{ppm}$ and $400 \mathrm{ppm}$ ) of spinosad and indoxacarb as given in table 1.

All insecticides gave statistically significant mortality of first instar larvae of $H$. armigera as compared to the control. After 24 hours of exposure maximum mortality was noted in the treatment of a 400 ppm concentration (7.000) and minimum mortality was noted in the 100 ppm concentration (3.667). Concentrations at $200 \mathrm{ppm}$ (5.667) and 300 ppm (6.667) were found statistically non-significant when compared with the treatment of 400 ppm concentration. After 48 hours of exposure 300 ppm concentration also gave complete mortality (7.000) and was statistically non significant with 200 ppm (6.333) and significant with 100 ppm (5.333) concentrations.

After 24 hours, 300 ppm and 400 ppm of indoxacarb were statistically non-significant when compared and gave complete mortality (7.000). Concentrations of 100 ppm (4.667) and 200 ppm (5.667) were also found to be statistically non-significant. Concentrations of 300 ppm and 400 ppm were statistically significant when compared with $100 \mathrm{ppm}$ and 200 ppm concentrations. After 48 hours of exposure, the 200 ppm concentration also gave complete mortality (7.000) and was statistically non-significant when compared with 100 ppm concentration (6.667).

For first instar, 300 ppm spinosad and 200 ppm indoxacarb can give complete mortality after 48 hours.

\section{Second Instar}

The mortality of newly moulted second instar larvae of $H$. armigera noted 24 and 48 hours after treatment with four different concentrations (100 ppm, 200 ppm, $300 \mathrm{ppm}$ and $400 \mathrm{ppm}$ ) of spinosad and indoxacarb is given in table 2 .

When second instar larvae were treated with four different concentrations of spinosad all the treatments were statistically significant when compared with the control. A 400 ppm concentration gave maximum mortality (2.667) and was at par when compared with 200 ppm (2 000) and 300 ppm (2000) concentrations. Minimum mortality was noted in 100 ppm concentration $(1000)$ and was at par?

Table 1. Mean mortality of first instar larvae of H. armigera treated with spinosad and indoxacarb after 24 and 48 hours

\begin{tabular}{|c|c|c|c|c|}
\hline \multirow{2}{*}{ Concentrations } & \multicolumn{3}{|c|}{ First instar } \\
\cline { 2 - 5 } & \multicolumn{3}{|c|}{ spinosad } & $24 \mathrm{~h}$ \\
\cline { 2 - 5 } & $24 \mathrm{~h}$ & $48 \mathrm{~h}$ & $4.667 \mathrm{~b}$ & $6.667 \mathrm{a}$ \\
\hline $100 \mathrm{ppm}$ & $3.667 \mathrm{~b}$ & $5.333 \mathrm{~b}$ & $5.667 \mathrm{~b}$ & $7.000 \mathrm{a}$ \\
\hline $200 \mathrm{ppm}$ & $5.667 \mathrm{a}$ & $6.333 \mathrm{a}$ & $7.000 \mathrm{a}$ & $7.000 \mathrm{a}$ \\
\hline $300 \mathrm{ppm}$ & $6.667 \mathrm{a}$ & $7.000 \mathrm{a}$ & $7.000 \mathrm{a}$ & $7.000 \mathrm{a}$ \\
\hline $400 \mathrm{ppm}$ & $7.000 \mathrm{a}$ & $7.000 \mathrm{a}$ & $0.000 \mathrm{c}$ & $0.000 \mathrm{~b}$ \\
\hline Control & $0.000 \mathrm{c}$ & $0.000 \mathrm{c}$ & & \\
\hline
\end{tabular}

Means sharing similar letters in a column do not differ significantly at $5 \%$ probability

Table 2. Mean mortality of second instar larvae of $H$. armigera treated with spinosad and indoxacarb after 24 and 48 hours

\begin{tabular}{|c|c|c|c|c|}
\hline \multirow{2}{*}{ Concentrations } & \multicolumn{3}{|c|}{ Second instar } \\
\cline { 2 - 5 } & \multicolumn{2}{|c|}{ spinosad } & $24 \mathrm{~h}$ & $48 \mathrm{~h}$ \\
\cline { 2 - 5 } & $24 \mathrm{~h}$ & $48 \mathrm{~h}$ & $4.667 \mathrm{c}$ & $6.667 \mathrm{a}$ \\
\hline $100 \mathrm{ppm}$ & $1.000 \mathrm{~b}$ & $2.667 \mathrm{c}$ & $5.333 \mathrm{bc}$ & $7.000 \mathrm{a}$ \\
\hline $200 \mathrm{ppm}$ & $2.000 \mathrm{ab}$ & $3.333 \mathrm{bc}$ & $6.333 \mathrm{ab}$ & $7.000 \mathrm{a}$ \\
\hline $300 \mathrm{ppm}$ & $2.000 \mathrm{ab}$ & $4.000 \mathrm{ab}$ & $7.000 \mathrm{a}$ & $7.000 \mathrm{a}$ \\
\hline $400 \mathrm{ppm}$ & $2.667 \mathrm{a}$ & $4.667 \mathrm{a}$ & $0.000 \mathrm{~d}$ & $0.000 \mathrm{~b}$ \\
\hline Control & $0.000 \mathrm{c}$ & $0.000 \mathrm{~d}$ & & \\
\hline
\end{tabular}

Means sharing similar letters in a column do not differ significantly at $5 \%$ probability 
with 200 ppm and 300 ppm concentrations which were statistically non significant among themselves. After 48 hours maximum mortality was noted in treatment of 400 ppm concentration (4667) and was at par with 300 ppm concentration (4000). 300 ppm concentration was at par with? 200 ppm (3 333) and 100 ppm concentration (2 667) which gave minimum mortality.

After 24 hours exposure of different concentrations of indoxacarb complete mortality was noted in the $400 \mathrm{ppm}$ concentration treatment $(7000)$ and was at par? with the 300 ppm concentration (6333). 300 ppm concentration was at par with 200 ppm (5333) and significant along with the 100 ppm concentration (4 667) which gave minimum mortality. After 48 hours of exposure $300 \mathrm{ppm}$ and 200 ppm concentrations gave complete mortality (7 000) and were statistically non-significant with the $100 \mathrm{ppm}$ concentration (6 667).

For second instar larvae 400 ppm spinosad give maximum mortality (4667) and 200 ppm of indoxacarb give complete mortality after 48 hours.

\section{DISCUSSION}

The results of the present study showed that indoxacarb is more toxic to $H$. armigera compared to spinosad. The same results were observed by Rani et al. 2005. They tested indoxacarb and spinosad against $H$. armigera and they found indoxacarb more toxic to $H$. armigera than spinosad. In this study it was observed that for all the stages of $H$. armigera, indoxacarb was found to be more toxic than spinosad.

Karabhantanal and Awaknavar (2004) and Ali et al. (2002) do not agree with the results of the present study. They conducted experiments to observe the toxicity of spinosad and indoxacarb to second instar larvae of $H$. armigera. They found spinosad more toxic than indoxacarb as spinosad caused a higher mortality rate than indoxacarb for a specific time.

First instar larvae was observed to be more susceptible to spinosad and indoxacarb. Ramos et al. (2004) also showed that spinosad was more active on first instar larvae of $H$. armigera. All the concentrations of indoxacarb gave maximum mortality in less time i.e. $24-48$ hours for both the instars. Abid and Cagnieul 2003 also conducted an experiment on the toxicity of indoxacarb to different instars of $H$. armigera. They observed that 24-46 hours are sufficient to kill most of the stages of $H$. armigera.

In the present study, it is clear that for both of the insecticides first instar is more susceptible. Hence, in the field, chemical control should start at the early stages to control $H$. armigera. For a better understanding about the chemical control in the field, further information about the persistency of insecticides is necessary. Previous studies showed that indoxacarb and spinosad are safe, selective insecticides (Grafton-Cardwell et al. 2003). Results showed that these insecticides are very effective as maximum mortality was noted when using both insecticides and thus, they can be used in the Integrated Pest Management programme of any crop.

\section{REFERENCES}

Abid R., Cagnieul P. 2003. Indoxacarb: a new insecticidal ingredient against fruit moths. Colleque international tomate sous abri, protection integree - agriculture biologique. Avignon, France, 19 Sep. 2003: 17-18.

Ahmad M., Saleem M.A., Ahmad M. 2005. Time - oriented mortality in leafworm, Spodoptera litura (Fab.) (Lepidoptera: Noctuidae) by some new chemistry insecticides. Pak. Entomol. 27 (1): 67-70.

Ahmad M., Arif M.I., Ahmad Z. 1999. Patterns of resistance to organophosphate insecticides in field populations of Helicoverpa armigera in Pakistan. Pestic. Sci. 55 (6): 626-632.

Ali A., Ahmad N., Aheer G.M., Karar H., Ali I. 2002. Comparative efficacy of new vs. old chemistry insecticides for the control of Helicoverpa armigera $(\mathrm{Hb}$.) on cotton crop. Pak. Entomol. 24 (2): 121-124.

Anonymous 1990. Proposed insecticide/acaricide susceptibility tests. IRAC method No 7 Bull. Eur. Plant Protect. Org. 20: 399-400.

Cameron P.J., Walker G.P., Herman T.J.B. 1995. Development of resistance to fenvalerate in Helicoverpa armigera (Lepidoptera: Noctuidae) in New Zealand. N. Z. J. Crop Hortic. Sci. 23: 429-436.

Grafton-Cardwell E.E., Godfrey L.D., Chaney W.E., Bentley W.J. 2005. Various novel insecticides are less toxic to humans, more specific to key pests. California Agric. 59 (1): 29-34.

Gunning R.V., Balfe M.E., Easton C.S. 1992. Carbamate resistance in Helicoverpa armigera (Hubner) (Lepidoptera: Noctuidae) in Australia. J. Aust. Entomol. Soc. 31 (2): 97-103.

Karabhantanal S.S., Awaknavar J.S. 2004. Efficacy of some insecticides against tomato fruit borer, Helicoverpa armigera (Hubner). Pest Manage. Econ. Zool. 12 (2): 131-136.

Nasreen A., Mustafa G., Ashfaq M. 2003. Selectivity of some insecticides to Chrysoperla carnea (Stephen) (Neuroptera: Chryopidae) in laboratory. Pakistan J. Biol. Sci. 6 (6): 536-538.

Ramasubramanian T. 2004. Magnitude, mechanism and management of pyrethroid resistance in Helicoverpa armigera Hubner in India. J. Entomol. 1 (1): 6-11.

Ramos J.M., Lechuga A., Hatem A.E.S., Osuna E.V. 2004. Come paration of susceptibility of Spodoptera littoralis (Boisduval) and Helicoverpa armigera (Hubner) larvae to spinosad, a natural insecticide. Bol. de Sanidad Vegetal, Plagas 30 (3): 573-580.

Rani S., Gupta G.P., Birah A., Raghuraman M. 2005. Relative tox‡ icity of novel insecticides to American bollworm (Helicoverpa armigera). Ind. J. Agric. Sci. 75 (4): 235-237.

Regupathy A., Rajavel D.S., Rajkumar S., Russell D. 1999. Present status of insecticide resistance in Helicoverpa armigera and its management in Tamil Nadu, India. p. 48-55. In: Proc. ICAC-CCRI Regional Consultation Insecticide Resistance Management in Cotton. CCRI, Multan. Pakistan. 28th June-1st July 1999.

Thirasack S. 2001. Yield losses assessment due to pests on cotton in Lao PDR. Kasetsart J. Nat. Sci. 35: 271-283.

Torres-Vila L.M., Rodriguez-Molina M.C., Lacasa-Plasencia A., Bielze-Lino P. 2002. Insecticide resistance of Helicoverpa armigera to endosulfan, carbamates and organophosphates: the Spanish case. Crop Protect. 21 (10): 1003-1013.

Williams T., Valle J., Vinuela E. 2003. Is the naturally derived insecticide Spinosad compatible with insect natural enemies? Biocontrol Sci. Technol. 13 (5): 459-475. 


\section{POLISH SUMMARY}

SKUTECZNOŚĆ ZWIĄZKÓW INDOXACARB

I SPINOSAD PRZECIWKO LARWOM

PIERWSZEGO I DRUGIEGO POKOLENIA

HELICOVERPA ARMIGERA PRZY

WYKORZYSTANIU METODY ZANURZANIA LIŚCI

W warunkach laboratoryjnych, testowano różne stężenia związków indoxacarb i spinosad przeciwko lar- wom Helicoverpa armigera. Wyniki wykazały, że te insektycydy są wysoce skuteczne. Obserwowano maksymalną skuteczność wywołana przez oba insektycydy i moga one być używane w programie Integrowanej ochrony roślin dla każdej uprawy. Dla pierwszego pokolenia, 300 ppm spinosadu i 200 ppm indoxakarbu może spowodować całkowitą śmiertelność po 48 godzinach. Dla larw drugiego pokolenia 400 ppm spinosadu może wywołać maksymalną śmiertelność $(4,667)$, podczas gdy 200 ppm indoxakarbu może być przyczyną całkowitej śmiertelności po 48 godzinach. 